\title{
The socialization of the independence of migrant workers children
}

\author{
Ikhda Maulida Agustina \\ Department of Sociology \\ Faculty of Social and Political Sciences, Universitas Airlangga \\ Address: Jalan Dharmawangsa Dalam, Surabaya 60286 \\ E-mail: Ikhdamaulida31@gmail.com
}

\begin{abstract}
The family is the primary socialization agent that has the function to shape the character of children. The presence of both parents in a family is able to provide great opportunities for children to obtain their rights including children who live in migrant workers' families. The thing that caught the attention of the researchers was the process of parenting especially socialization regarding independence carried out by the caregivers, as an effort to form the character of an independent child and fulfillment of children's rights and minimize the label given to children in the family of migrant workers. This study uses qualitative methods. The data collection in this study used in-depth interviews, the determination of the informants in this study used snowball random selection of informants and rolled from one informant to another informant without limitation on the number, in the study there were 7 informants who were caregivers of the children of migrant workers' families, the age of the children cared for is 8-18 years. The theories used in this study are the theory of Symbolic Interactionism from Herbert Blumer and Theory of Socialization Patterns from Elizabeth B. Hurlock. The results obtained from this study are that foster parents have meaning about independence derived from parents, experience and the surrounding environment. The meaning that is owned by foster parents is then disseminated to the children of migrant workers' families. The meaning of independence inherent in foster parents has an impact on the pattern of socialization that is applied to migrant workers' children. Independence is interpreted as disciplinary learning using authoritarian socialization patterns, independence which is interpreted as encouraging children to apply democratic socialization patterns and independence which is interpreted as self-habituation for children using permissive socialization patterns.
\end{abstract}

Keywords: socialization, independence, children of migrant workers' families

\section{Introduction}

The family is the primary socialization agent that functions as the shaping of children's characteristics. Through the process of socialization and internalization carried out by family members, it can shape the character of the child and determine the child's character to be good or bad. The family, especially the nuclear family, has its role in shaping the character of the child, besides that the family is the first institution to instil and teach the values and norms of social norms that exist in society. The values instilled by the family then become provisions for children to live in a dynamic society (Sutiana et al. 2018).

The existence of parents is essential in the process of child development to educate, ensure and care for children. Parents who are complete will have an excellent chance for their children to obtain children's rights as stated in the Convention on the Rights of the Child which defines a child as a human being who is not yet 18 years old. Therefore, intact parents are essential in the family because they can influence the formation of the child's personality. Children tend to pay attention to the attitudes, actions, and words of their parents towards themselves and their parents with other people such as friends, relatives, relatives and others (Lailiyah 2018).

The reality of the whole family life so that it can carry out the parenting process properly is not always achieved; several factors significantly affect family relationships that must be done over a long 
distance. One of them is the economic factor behind one parent or even both parents reluctantly leaving their children to become migrant workers or TKI. Individuals who decide to become migrant workers will have an impact on the families left behind, both husbands, wives and children. The reduction of one of the nuclear family members creates an imbalance in the family that is left behind. In this case, there is a change in a family function. Imbalances that occur in the family can affect child development.

Labour migration is increasingly prevalent, especially among people in developing countries that experience rapid urbanization and have a high level of inequality. Indonesia is one of the countries that supply TKI to several countries, many of the factors behind them becoming TKI, one of which is very crucial is the economic factor.

Lailiyah (2018) has conducted a study related to childcare in the families of TKI, entitled Problems of Child Care for Migrant Workers' Families. In that research, it was found that the problematic child care originates from things that are contained in the family background, the motivating factors for parents to work as migrant workers, the meaning of children in the migrant workers' family and children's views on parents who work as migrant workers. According to the journal, there are three categories of parenting that are done. First, children who are cared for by their biological mother when their father leaves them as migrant workers will tend to be authoritarian as caregivers. Second, children who are cared for by their aunts tend to be permissive of their caregivers. Third, children cared for by their relatives when both parents become migrant workers. They tend to be a combination of permissiveness and authoritarianism in caring for them.

Another study that examines the care of children in migrant families in Africa is a study by Alaazi et al. (2018), which seeks to see the relationship between parenting and disciplinary practices applied in African immigrant families. In practice, the discipline imposed by immigrant parents is corporal or physically binding, which is different from the provisions of the applicable law in Canada, which is free. So this research focuses on the disciplinary practices carried out by immigrant parents in Alberta to their children.

Other relevant research from MacDonald and Hastings (2008) which looks at how fathers are involved in childcare for children with intellectual disabilities, found results based on surveys that have been conducted that fathers have full awareness of their roles. So that involvement in the care of children with intellectual disabilities is evident, especially in matters related to socialization to children.

Other studies have looked at the impact of the absence of a mother in a child's life on academic achievement, cognitive development and emotional well-being in children. Research conducted by Xu et al. (2019) shows that maternal absence significantly impacts cognitive and emotional development and academic achievement of children, compared to the absence of a father from the family.

This study looked at the forms of care carried out by those who cared for the children when the parents worked as migrant workers. As is well known, children are individuals who have the right to socialization in the family through the whole family. The purpose of this socialization is so that children can develop both mentally, emotionally and socially. However, the problems that often occur in the family often place children in the position of victims based on the parents' decisions, either directly or indirectly. So that the socialization carried out through childcare does not run smoothly due to the vacant role of one parent. That is what then has an impact on children's development both in terms of mental, emotional and social imperfections that lead to imbalances in this development. Reported by detiknews (in detik.com), it is said that children whose parents are Indonesian migrant workers experience many psychological problems, including emotional disorders, hyperactivity and behaviour problems. That is evidenced in research conducted by UGM researchers regarding the impact of international migration on migrant families and children. Sukamdi et al. (no date) stated that the difference between children living in migrant and non-migrant households. Children in the TKI family were identified as having more symptoms of social problems, causing more problems and 
hyperactivity. According to Sukamdi et al. (no date), children who come from TKI families tend to be more restrained and closed when expressing feelings or when seeking support or assistance.

The problems as mentioned then attracted the attention of researchers in examining more deeply the socialization carried out by parents to children in the families of TKI. In this case, the parents are those who are directly related to the child in the process of caring and socialization during the child's development, whether mother, aunt/uncle, grandparent, brother-in-law or a distant relative.

Based on the description above, this study aims to understand and explore how the socialization of independence of parents to children of TKI families in Gresik Regency. In other words, this study aims to examine the differences in the socialization patterns of independence applied to children of migrant workers' families. Therefore, this study entitled the socialization of independence for children of the TKI family.

\section{Methods}

This study uses a qualitative research type, which is a research method used to analyze phenomena that occur in society. The purpose of qualitative research is to obtain a complete picture related to a thing understudy that is related to the ideas, thoughts, perspectives, or opinions of the individuals being studied.

In this study, Gresik Regency (see Figure 1) is the location chosen by the researcher as the research site. Gresik is one of the industrial cities in East Java. Many industries absorb labour both from inside and outside the Gresik Regency. The large number of the labour force from outside the region that is absorbed in the Gresik industry results in a gap between the Gresik labour force and the foreign labour force. That makes many people choose to leave the country to work as migrant workers. Determining the research location is, of course, based on considerations, namely the reasons parents had when they decided to become a migrant worker and return to their country of origin within a certain period. According to Mr. Samsul, one of the areas of workforce placement and expansion of employment opportunities, the Gresik Manpower Office said that the reasons for the Gresik community to become migrant workers were economic and environmental factors. He said that the environment is like neighbours, family or close relatives who have successfully become migrant workers. He also said that migrant workers who returned to their country of origin were based on certain conditions such as the Islamic holidays, Eid al-Fitr or Eid al-Adha, their family members who were sick or married and the contract period ended.

This study uses the technique of determining the snowball subject, how to collect and select informants from within a continuous network of relationships. The criteria for the subjects in this study were the parents worked as migrant workers for five years, cared for the children of the TKI family for three years, and the age of the children who were cared for was from 8-18 years. The informants are DWI, ITH, NRL, SMH, HDY, SBH and WWN. The data collection techniques used in this study were an indepth interview and observation. 
Agustina: The socialization of the independence of migrant workers children

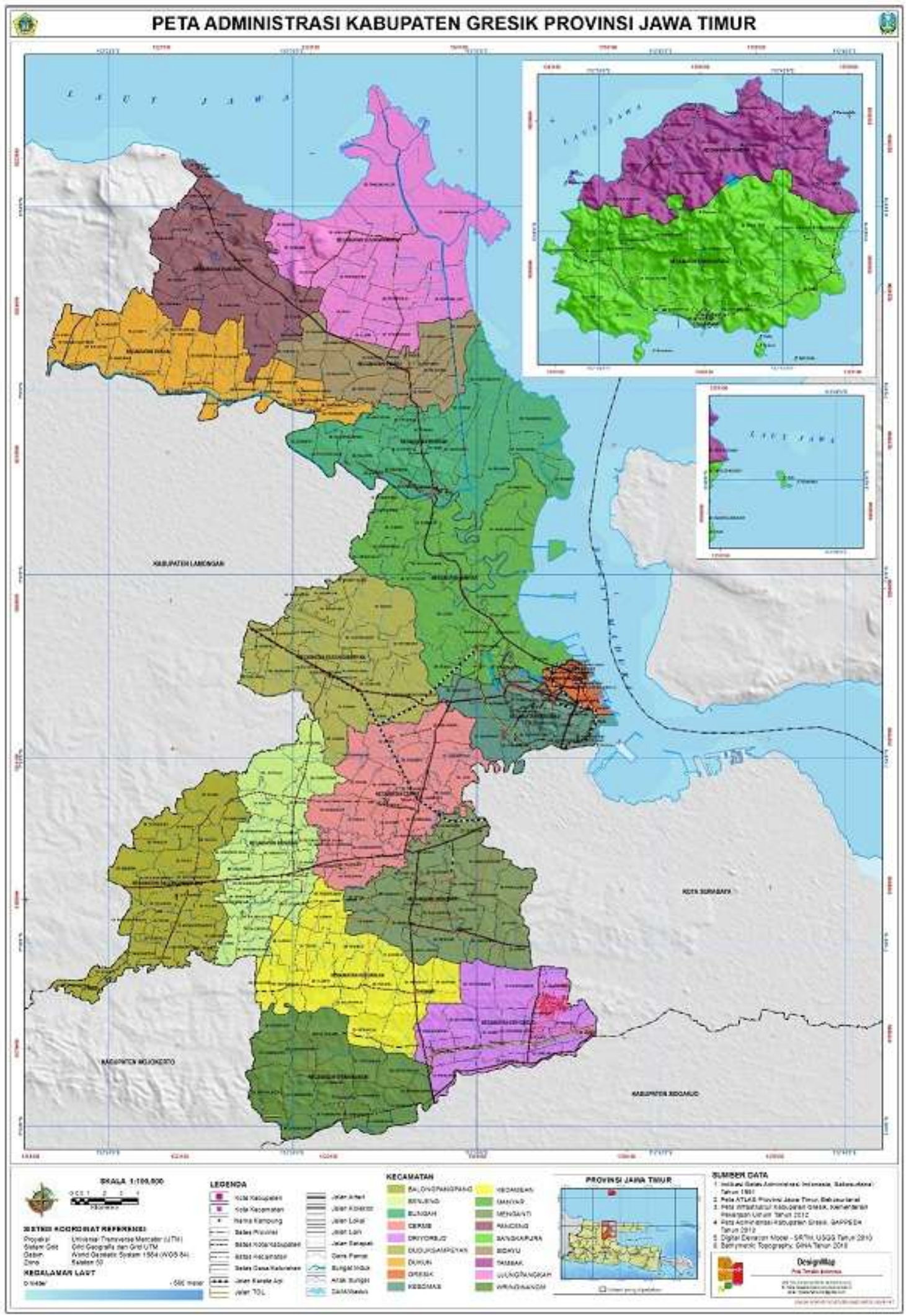

Figure 1

Gresik Regency administrative map (https://peta-kota.blogspot.com/2017/01/peta-kabupaten-gresik.html) 


\section{Results and Discussion}

\section{Parents Knowledge about Independence}

This knowledge stems from the beginning when parents recognize independence. In the process of implementing independence, of course, each individual goes through a process of introduction or socialization. Therefore, the independence that every individual has must come from the socialization that has occurred in his life. Some of the interviewed informants said that knowledge about independence was obtained from childhood, from learning provided by parents. Also, other informants said that knowledge about independence was obtained from formal institutions, namely schools, where teachers have always taught things related to independence since elementary school. Informants from the surrounding environment also obtained knowledge of independence.

\section{Children's Understanding of the Socialization of Independence}

Independence is an essential aspect of child development. The socialization of independence will affect children's learning activities, behaviour and cognition and help children recognize their responsibilities. Instilling independence in children can develop children's abilities to think and act on their own will to meet their needs so that children are no longer dependent on others but become independent individuals. The socialization of independence carried out by parents can be said to be good measured by the child's understanding of the socialization of independence carried out by the parents. In the process, children's understanding varies according to the child's developmental age.

Children's understanding of the socialization of independence implemented by parents is reflected in the child's daily behaviour. Several informants said that children did not fully understand independence. So that parents still have to remind people related to independence. On the other hand, the informant said that the understanding possessed by children was applied in their daily behaviour such as maintaining the cleanliness of the environment and themselves, time discipline, being responsible for daily expenses and income.

\section{The Meaning of Independence for Caregivers}

In general, independence is the ability of a person to carry out a day-to-day activity alone or with a little guidance according to the stage of individual development. The socialization of independence will show optimal results if it is done from an early age, starting from making habits that teach children to do it alone and repeatedly. That is because early childhood is more comfortable to apply things related to independence.

The process of socializing independence in children takes place through stages following the child's development as well as guidance and supervision from parents. The encouragement and rewards given by parents to children can increase children's motivation to become independent. Parents are the people closest to and responsible for the child's life, but not for children whose parents are migrant workers. Children must live separately from one or both parents so that the child lives with close relatives or carers. In the socialization process, each parent has a meaning that is used to socialize independence to children.

Some parents interpret independence as learning to discipline children, where children must be taught to be disciplined in any case so that children can manage their own decisions and take responsibility. Besides, some interpret independence as a child encouragement. In this case, parents have confidence in their children to be able to do something they want; parents are also more supportive of what the child wants than giving children restraint. Other parents have the meaning of independence as things that can shape children's life habits, such as instilling clean habits, respecting the time and serving oneself. The habit starts with giving examples by parents. 


\section{Rules for Disseminating Independence}

Socialization is a learning process that lasts a lifetime for each individual. In the socialization process, several things need to be conveyed, including the values and norms that apply to a society, in general, the delivery of values and norms cannot run correctly without the role of the supporting aspects of the socialization process. The aspects of the socialization process consist of rules and laws that are established as the socialization process takes place.

The reality in the field shows that the rules applied by parents adjust to how parents interpret independence. Several informants said that the regulations given did not always restrain children, but were only limited to supervising children's interactions or supervising children when they left the house. In the socialization process, parents do not apply restrictive rules to their children; they realize that restrictive rules are not good enough for children's development. On the other hand, parents provide good rules to restrain the child by imposing restrictions on the child. That is done to establish independence in children.

\section{The punishment given by parents when a child is guilty}

Child care is one of the efforts to fulfil children's rights, including full care that is carried out by parents. However, in this study, it looks at how parents fulfil their children's rights in terms of the care they take when the child is left behind by one or both of his parents to become migrant workers abroad. In the process of caring for children, it will run optimally when there is a fair socialization process, wherein the socialization aspects of the socialization, namely the rules and penalties given to them, must run in harmony to educate children by the values and norms that apply to society.

The life of children in the process of socializing independence cannot be separated from mistakes made. Mistakes that can be made intentionally or unintentionally, for those who deliberately make mistakes they understand that they have violated the rules that have been applied, sometimes there is also unintentional behaviour that violates the rules. Even though the rules have been implemented in socializing independence, they still cannot be carried out correctly by children. When a child makes a mistake, the parents will punish the child as a warning sign. Punishment itself is a sanction for violating the rules, has a character that limits children's behaviour. The punishments given can be physical or advice. Parents giving punishment to children have the aim of educating children to be responsible for the mistakes of their behaviour. That can make children more motivated to carry out the rules applied by parents.

In reality, in the field, it shows that parents give punishment to their children in quite a variety of ways. Every parent said that the punishment that is often given has a degree of judging something that is the child's fault. First, parents give warning to children, remind and show children where mistakes are. Second, scolding the child when it is difficult for the child to be given understanding, the parents scold the child and give a stern warning to the child. Third, parents confiscate facilities given to children, such as cutting pocket money or confiscating cell-phones. They said that they never gave physical punishment to children.

\section{Constraints in the Socialization of Independence}

In socializing independence to children of TKI families, it is inseparable from the emergence of obstacles faced by those who care for them, whether mothers, aunts or siblings. As for the obstacles faced by those who care for it, it is often difficult if the child is sick, the nature of the child is challenging, and the child does not want to obey the carer.

Being a single parent is not easy; taking care of children and taking care of household needs as a whole is the obligation of the parents of children who are left to work as migrant workers. As parents, of course, they have their respective obstacles when raising their children. The obstacle that often appears is the nature of the child, such as stubbornness, disobedience and often closure. Apart from the nature of the child, parents admit that when a child is sick, it is also an obstacle to raising children. Because at 
that time, parents will take care of their children, accompanied by taking care of all the children's needs. Parents admit that this is an obstacle and difficulty in caring for the children of the TKI family.

\section{The Meaning of Caregivers for Independence}

According to Blumer, symbolic interactionism refers to the distinctive nature of human interactions. Its power is that humans translate and define each other's actions. Not just a reaction is given by other individuals but based on the meaning of the action. The interaction between individuals in which there is the use of symbols aims to interpret and understand each other the meaning of existing actions. It can be said that the process of human interaction is not a process in which the stimulus automatically and immediately creates a response and response. However, the stimulus received and the response that occurs is based on the interpretation process of the akrtor. According to Blumer, the key to this theory is the interpretation process which mediates between the stimulus and response. Based on Blumer's three premises which have been mentioned in Poloma (2007), by caregivers, socializing independence to children is based on the meaning they have. In interpreting the importance of independence for children, the caregivers have opinions that are not much different from one another, and they say that independence is everything that is done by themselves with their own will with full responsibility. However, the acquisition of meaning is admittedly quite diverse, some of the informants admit that independence has been instilled from an early age by families, especially parents so that they interpret independence will be more effective if instilled by parents and done early. However, on the other hand, the existence and suitable environmental conditions can affect the development of a person's character.

Furthermore, Blumer in Poloma (2007) mentioned that the premise of the meaning possessed is enhanced through a process of social interaction that takes place between the caregiver and the children of the TKI family. The process of socialization of independence carried out by the caregiver is adjusted to the conditions of the child's development, from several informants who were found to have children aged 8 to 16 years, where at that age the child's development is at the adolescent stage. Adolescent children generally have emotional levels that often fluctuate apart from that at that age, and the children are in search of their identity so that they try many things that are considered right. The socialization of independence carried out by the caregivers must be able to adjust the child's age development so that the child can understand well and the children can protect or protect themselves from anything terrible from outside. The meanings obtained by the caregivers serve as essential guidelines for the process of socialization of independence. When caregivers apply independence to children as a socialization process, it is called social interaction that takes place between the caregiver and the child in the TKI family.

When carers socialize independence to children of migrant workers' families, they always adjust to the understanding that these children have. Different children's conditions and different children's development also affect the way the caregiver socializes independence following the child's development and age. Based on the findings of data obtained from the field, self-reliance planting is carried out by carers according to the age of the child.

Some informants who have children aged 8 to 10 years, the informants' cultivation of independence starts from necessary activities related to their daily needs. Besides that, they also do not force children always to obey the instilled values of independence. They only gave examples so that the child could learn on their own and reminded them if they made mistakes in contrast to other informants who have teenagers. The four of them no longer instil fundamental independence, but instead instil responsibility for themselves and the decisions they make, discipline and introduce excellent and bad. Efforts are made to cultivate independence by the caregivers not to force the child. Still, they provide space for the child to move; this is so that the children of the TKI family can slowly understand the meaning of independence through socialization carried out by the caregivers.

Blumer also states that one's meaning of something comes from the ways other people act on it to that something. The actions they take will create boundaries for others. In this research, it can be seen that 
the initial meaning of the informants regarding independence. That comes from their parents, and their environment has become a way of life until now. Then the meaning of independence is conveyed to the children of the TKI family through socialization. However, the socialization of independence that is carried out also adapts to the child himself's condition and character. The different conditions and characteristics of the children can affect the understanding of the children of the TKI family regarding the independence socialized by the caregivers. Different understandings related to the instilled independence have an impact on the socialization patterns carried out by the caregivers, from enforcing strict rules to strict limits to control children's actions.

\section{The Pattern of Self-Reliance Socialization to TKI's Family Children}

The socialization process that takes place has a vital role in the survival of each individual, especially in child development. The socialization that is carried out can help children adjust to the values and norms that apply in society. The vital role of socialization agents is a measure of the success of socialization of independence to children. Socialization agents are small groups that are closely related to individuals who wish to receive socialization.

Concerning this research, the role of caregivers is significant in the socialization process of independence. Where the carer is the primary socialization agent for the children of the TKI family, because the carers referred to here are those who are directly involved in caring for the child directly, so that the carer has a dominant role in the socialization process.

The condition of the TKI family's children affects the socialization process, especially with the condition of the children who have entered school age and have begun to socialize with the outside world. Hence, caregivers need to implement the socialization process about the value of independence. Based on the meaning possessed by the caregiver to form a pattern of socialization that is applied to children.

\section{Independence is defined as the Cultivation of Discipline in Children.}

Independence is essential to children as an effort to improve the child's discipline. This view was said by some of their informants saying that independence is essential to instil in children from an early age, this is done by carers to get TKI family children not always dependent on others when away from his parents. In the socialization process, how long it takes for parents to become migrant workers and how long the child is cared for by the carer affects the form of socialization applied by the caregiver. Therefore, the informants who interpret independence as the cultivation of discipline in children use authoritarian socialization patterns. Where there is more emphasis on rigid rules and tends to restrain the socialization process for children, likewise with appreciation or praise given to children is rarely done. Parents also do not encourage children to be able to make decisions about their actions.

\section{Independence is defined as Child Encouragement}

Giving confidence to children to be able to make their own decisions. Educating children must provide restrictive rules, but giving children trust will help form an independent child's character. When children are trusted to make their own decisions in determining what they want, the child will think about how to make decisions and be accountable. In the socialization process, the informants used a form of democratic socialization. Socialization using a democratic pattern is usually carried out by families who prioritize the wishes and wishes of the child. In the process, the child is always given an explanation and reasons that help the child must comply with the parents' rules. Parents also prioritize the learning process for children compared to using punishment when children make mistakes. The same thing is done when children get appreciation or pride from their parents so that the parents will give praise to the child. A family with a democratic parenting style will shape the child's personality and increase the attitude of self-control towards the child. 


\section{Independence is defined as Self-Habit}

Providing examples in everyday life is done by caregivers to accustom children to living independently. Independent, which is interpreted as the ability to do everything on their own, the caregiver begins to provide examples of small things to children to form children's independent attitudes. In caring for children, informants use permissive patterns to socialize Independence to children.

Socialization with a permissive pattern is that parents allow their children to behave and never give punishment to children. In this pattern, the child is left to search and find a way to impose limits on his behaviour. Also, this permissive pattern, the supervision carried out by parents is very loose, even not at all. As a result, this socialization is running imperfectly, and the learning given to children is not indepth. In this socialization, pattern parents give full freedom to children to do something and give confidence to children to be able to choose a suitable environment for themselves.

\section{Conclusion}

This study finds the meaning of parents towards independence and how parents socialize independence to children of the TKI family so that the conclusions are drawn between them. First, the meaning of the independence that grows in caregivers is obtained from previously received learning, such as parents, experiences from the surrounding environment. Then the meaning of independence becomes a guideline for caregivers in socializing independence to children of migrant workers' families. Second, the independence which is interpreted as learning related to the discipline to children by caregivers. So caregivers apply an authoritarian socialization pattern, in socializing the independence of caregivers to provide restraint to children and limit children's movement towards the environment. Third, the independence which is interpreted as a driving force for children, caregivers socialize independence with a democratic pattern that provides space for children to do what they want. Fourth, independence is defined as self-habituation carried out by caregivers in socializing independence, namely by exemplifying daily activities, including personal hygiene and self-serving. In the socialization process, the caregivers apply a permissive socialization pattern to the child.

\section{References}

Alaazi DA, Salami B, Yohani S, Vallianatos H, Okeke-Ihejirika P, \& Nsaliwa C (2018) Transnationalism, parenting, and child disciplinary practices of African immigrants in Alberta, Canada. Child abuse \& neglect 86: 147-157. 10.1016/j.chiabu.2018.09.013.

Anak yang Ditinggal Ortu Jadi TKI Banyak Alami Masalah Psikologis (2011) [Diakses Juni 2019]. http://m.detik.com/news/berita/d-1754261/anak-yang-ditinggal-ortu-jadi-tki-banyak-alamimasalah-psikologis.

Lailiyah F (2017) Problematika Pengasuhan Anak Pada Keluarga TKI (Studi Di Desa Golokan Kecamatan Sidayu Kabupaten Gresik). Skripsi, Universitas Airlangga, Surabaya.

MacDonald EE \& Hasting RP (2008) Mindful Parenting and Care Involvement of Father of Children with Intellectual Disabilities. Journal of Child and Family Studies 19 (2): 236-240.

Peta Kabupaten Gresik (2017) [Diakses tanggal 24 Oktober 2020]. https://petakota.blogspot.com/2017/01/peta-kabupaten-gresik.html.

Poloma MM (2007) Sosiologi Kontemporer. Jakarta: PT Raja Grafindo Persada

Sukamdi, Wattie AM, Susilastuti DH, Tamtiari W, Pitoyo AJ, Purwatiningsih S, \& Kiswanto E (no date) Dampak Migrasi Internasional Terhadap Keluarga dan Anak yang Ditinggalkan: Studi Kasus Indonesia

[Diakses

Juni

2019]. 
Agustina: The socialization of the independence of migrant workers children

Indonesiahttp://smeru.or.id/sites/default/files/events/05_the_impacts_of_parental_migration_on_he alth_and_well-being_-_dr_sukamdi_0.pdf

Sutiana MA, Nandatia RP, A'yun Q, Prayogi AR, Imron A (2018) Pola Pengasuhan Anak pada Keluarga TKW di Kecamatan Srengat Kabupaten Blitar. Paradigma 06 (01): 1-6.

Xu Y, Xu D, Simpkins S, \& Warschauer (2019) Does it Matter which Parent is Absent? Labor Migration, Parenting and Adolescent Development in China. J Child Fam Stud 28: 1635-1649. https://doi.org/10.1007/s10826-019-01382-z. 